\title{
Exploring Six Muslim Teachers' Coping Strategies in Overcoming Mental Illness
}

\author{
Aishah Hanim Abd Karim \\ Kulliyyah of Education, \\ International Islamic University Malaysia \\ Kuala Lumpur \\ aishahanim@iium.edu.my
}

\begin{abstract}
This qualitative research explored Malaysian Muslim teachers' perspectives of mental illness and well-being with an aim to understand how they coped with their own condition of illness and the relationship between spiritual practices and mental health. Six public school teachers served as interview participants, all of whom had experienced a mental breakdown at some point in their career. Using a semi-structured protocol, the teachers were interviewed individually at different times and settings. An inductive content analysis was used to interpret the data for all participants. The findings showed four themes, namely medical treatment, religion, family and societal support, and positivity to be the dominant factors of coping. Four subthemes emerged from religious coping, i.e., prayers, Qur'an reading, protective factor, and diseases of the heart. These subthemes suggested an association between spiritual practices and mental well-being. Apart from seeking professional help and getting appropriate medical treatment, the study also revealed the importance of engaging in various spiritual practices such as performing the five daily prayers, zikr, salawat shifa', and reading the Qur'an, strategies that produced the feelings of peace and calmness in the participants which were instrumental in helping them cope with their illness and become productive teachers.
\end{abstract}

Keywords: Mental health, mental well-being, Muslim teachers, spiritual practices, religious coping

\section{INTRODUCTION}

People in general, hold negative beliefs about individuals with a mental illness, a psychological health problem that significantly affects how a person feels, thinks, behaves, and interacts with other people (Rice-Oxley, 2019). Mental illness comes in many forms and degrees of severity, ranging from something slight such as acrophobia (fear of heights) to conditions that are clinically serious such as schizophrenia and manic depression. These psychological conditions cause extreme mood swings, emotional outbursts and erratic behaviours, and those affected are often perceived as mad, dangerous, unpredictable, unattractive, unworthy and unlikely to be productive. Negative beliefs about mental illness among the public are remarkably constant although advances in the scientific understanding of the problem and wide ranging efforts to improve public understanding of it have been made (Wahl et al., 2012). Because of the negative stereotypes, people with a mental illness often suffer losses of personal relationships, social support, housing opportunities and employment (Wesselmann \& Graziano, 2010). 
The number of Malaysians affected by different forms of mental illness increases by the year. In the year 2000, about 10.7 percent of the population were affected (Jamaiyah, 2000); this was quite a high percentage although it was based only on hospital figures. In 2006, the figure increased to $11.2 \%$, escalating further in 2011 where about $12 \%$ of Malaysians suffered from depression and anxiety due to an inability to cope with stress at home and the workplace. In 2015, according to the National Health and Morbidity Survey, the figure shot to $29.2 \%$, constituting roughly 4.2 million Malaysians struggling with mental health issues (Figure 1). The same survey found that suicidal thoughts among teenagers aged 13 to 17 increased from 7.9 percent in 2012 to 10 percent in 2015. According to Tan Sri Lee Lam Thye, patron of the Malaysian Psychiatric Association (MPA), by the year 2020, mental health issues such as depression and anxiety are expected to be a major problem among Malaysians.

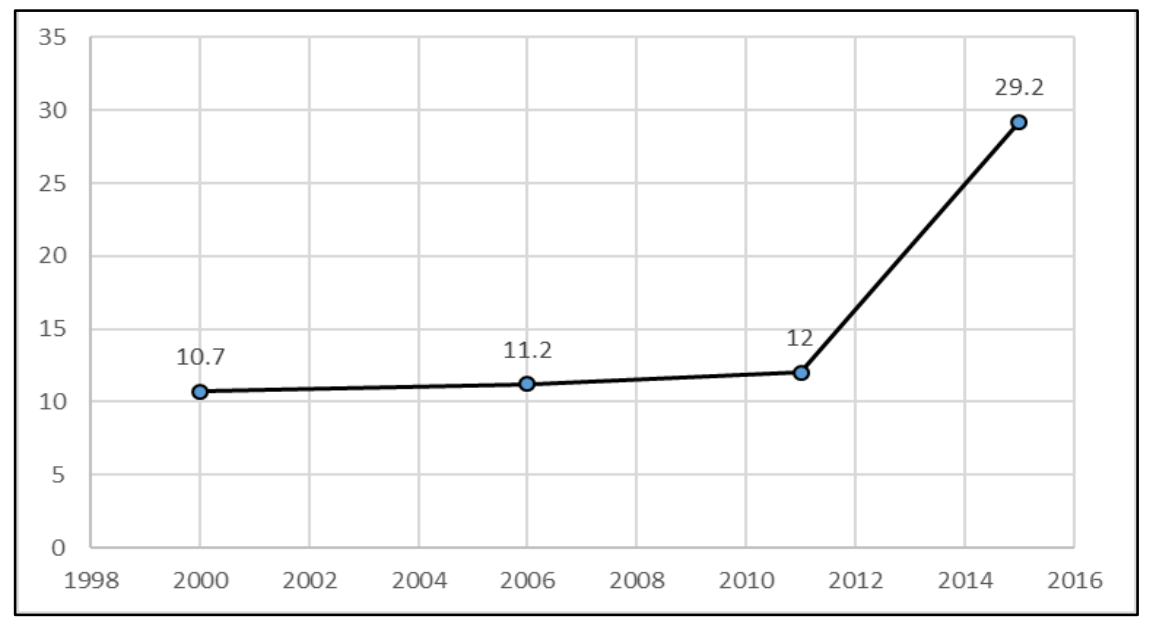

Figure 1. Malaysians Affected by Mental Illness 2000-2015 (in percentage)

Due to the lack of census data, documentation and official reports, the actual number of Malaysians living with mental health problems across the nation is unknown. There is reason to suspect that the total figure might be more than the numbers projected (Chong, Mohamad \& Er, 2013; Yeoh, Tam, Wong \& Bonn, 2017). Yet, the findings of several studies carried out in both urban and rural areas in Malaysia have placed the prevalence of mental illness in the population somewhere between 9.6 percent and 35 percent (Crabtree \& Chong, 2000; Perveen et al., 2017).

Teachers too are not immune to mental health issues. Due to the great demands of the teaching profession, many teachers experience negative mental health that is related to burnout, stress and depression. Burnout is defined as "a feeling of physical, emotional and mental exhaustion resulting from a chronic state of cumulative pressure or stress at work" (Weisberg $\&$ Sagie, 1999, p. 333). It can be characterized by emotional and physical reduction and negative feelings towards work and life, causing the affected individual to become intolerant with occupational pressures and work stress. Both physical and mental exhaustion positively and significantly influence teachers' decision to quit their jobs (Weisberg \& Sagie, 1999). Teacher burnout can also be influenced by other factors such as job satisfaction, poor working conditions, deadlines and time pressure, work-family conflicts, school type and amount of working hours (Milfont et al., 2008). Many teachers, even in Malaysia, have suffered from mental health problems and emotional exhaustion (Bauer et al., 2007; Naring et al., 2006; Othman \& Sivasubramaniam, 2019). Recently, Education Minister Dr Maszlee Malik gave a speech addressing Malaysian teachers' increasing mental pressure resulting from factors like domestic problems, financial issues, job uncertainty and living away from families. He expressed a well-justified concern--how can "disrupted psychological and emotional well- 
comprehension being" allow teachers "to carry out the teaching and learning process in a friendly and effective manner?" (Rajaendram, 2019).

Malaysia's Education Blueprint 2013-2025 states that education is a major contributor to the growth of the country's social and economic capital. Hence, the government is committed to transforming Malaysia's education system to ensure students are holistically equipped to allow them to succeed in the 21st century, with all the opportunities and challenges that this new era presents (MOE, 2013). Therefore, Malaysia needs quality teachers to ensure this aspiration is achieved (Bakar et al., 2014). According to the blueprint, the quality of teachers is the most significant school-based determinant of students' outcomes. The Ministry of Education aims to make teaching a profession of choice by enforcing higher entry standards into teacher training programmes, improving the effectiveness of pre-service and ongoing continuous professional development, and developing fast-tracking career pathways based on teachers' performances and competencies.

However, teachers may experience psychological, physical and behavioral problems as a result of a stressful working environment (Evans, 2003; Jurado, Gurpegui, Moreno \& de Dios, 1998; Ouellette et al., 2018; Othman \& Sivasubramaniam, 2019). In Malaysia, there are several cases of teachers reported to be suffering from poor mental health. For instance, a 28-year-old teacher from a northern Malaysian state was arrested for criminal trespassing in Singapore in January 2014. The teacher apparently had a long history of mental illness. In another case, a male teacher was apprehended for physically brutalizing four students in a secondary school up north. Judged to be suffering from stress and mental issues, the teacher was later asked to take a one-week leave and undergo a health test at a hospital (The Star, 14th February 2014). A third case involved a male teacher who filed a legal suit against a District Education officer and four others for transferring him to another school, claiming to have suffered a depression because of the transfer that separated him from his wife and children (The Star, 2nd January 2013).

The teachers involved in the three cases above were all Muslims. The cases prove that teachers are susceptible to psychological issues that can affect their mental health and wellbeing, just like people in other professions considered to be stressful, for instance medical doctors and law enforcement officers (Hooftman et al., 2015). In the teaching profession, teachers are burdened with excessive teaching load, marking workload, large classes, student discipline and extra-curricular activities outside their working hours. Given the nature of their work, teachers must be fully equipped with the knowledge and skills to manage stress and conflict in the workplace, and the ability to juggle the work-life balance. Skills development training, professional counselling services and stress management workshops should alleviate some of the emotional and psychological burden that weighs heavily on teachers.

While the causes of teacher stress and mental illness are quite well-researched (Manju, 2018; Mccarthy et al., 2016), how teachers cope with the illness is less studied. Specifically, how do Muslim teachers, who have been clinically diagnosed, cope with their mental illness issues? What coping strategies do they use? Does religious coping play a role in healing their mental condition? Thus, studies are needed to explore the issue of mental illness and coping among Muslim teachers in Malaysia, with a focus on the strategies used to alleviate adverse psychological pressures and the relationship between the use of spiritual practices and mental health. The choice of a qualitative study was deemed appropriate to obtain a in-depth perspective of these concerns. 


\section{THEORETICAL FRAMEWORKS}

\section{Langgulung's Theory of Mental Health}

Hasan Langgulung's (1986) theory of mental health states that in Islam, mental illnesses are related to diseases of the heart, such as self-praise, envy, avarice and love of wealth, frivolity, love of power and fame, love of the world, pride and arrogance, conceit, and ostentation. Ostentation (riya') refers to talk and behaviour that are intended to show off and impress others. It can also be defined as seeking to gain status in people's eyes by publicly displaying acts of ibadah (e.g., prayers, Qur'an reading and memorization) and other righteous deeds (e.g., acting charitable to look pious or dressing poorly to appear humble). These acts may lead to shirk.

Anger is the most dangerous disease of the heart because it could cause a person to act irrationally. It may also lead to envy. Envy (al-hasad) is caused by arrogance, pride, or wickedness. It may cause the heart to be discontent when the person sees the success and wealth of others. Envy is malevolent if the heart wishes for others to fail and lose their wealth. However, in some aspects, envy is acceptable. For instance, a Muslim may envy another Muslim in the performance of good deeds and ibadah, and sacrificing wealth for the sake of Allah (S.W.T.), and spreading knowledge to teach others. Hasad can be cured through knowledge ('ilm) and faith in Allah (S.W.T). If a person is knowledgeable, then he will be aware that being envious is harmful for himself and only brings benefits to the person he is jealous of. This is because being envious nullifies his good deeds and exposes him to Allah's wrath. His faith in Allah will teach him that Allah is just and gives to whomever He likes which could be a test. Being obsessed with envy can cause mental illness.

Avarice is another disease of the heart that can lead to greed, an overwhelming desire to possess more than is necessary. Excessive love of wealth is the main cause of avarice. The excessive love of wealth can make a person heedless from remembering Allah, turning his heart towards this world and causing it to be strongly attached to it. This can lead to a state of perpetual dissatisfaction with oneself. Another bad character of man mentioned by Langgulung (1986) is vain talk (lagha). Talking too much will lead to talking nonsense, boasting, lying and hurting others. Thus, Muslims should guard their tongues, talk wisely and only when necessary. The biggest evil act of the tongue is to gossip or backbite. This act is even more dangerous than adultery. An example of lagha is when a person starts to backbite about another person's character, occupation, clothes, ancestry, or other aspects to other people with the intention of damaging his or her character. Bad thoughts (su'uzzann) or negative perceptions about others also fall into this category. However, it is acceptable to relate somebody's character if it is for a good intention such as in getting justice for a certain individual, especially if the individual is being oppressed.

\section{Badri's Theory of Mental Health}

Another Muslim theory of mental health is based on Malik Badri's (1979) works on Islamic psychology. Badri (as cited in Abdul Wahab Khan, 2015) disagreed with the stimulus-response paradigm developed by the behaviourists in the early sixties because it was based on a mechanistic conception of human nature that was influenced by Darwinism and secular humanism. He believed that this paradigm needs to be humanized and be based on an Islamic understanding of human nature and its spiritual fitrah.

Badri created an intervention that came to be known as the "Cognitive Behaviour 
Therapy" (CBT) which combined Wolpe's desensitization therapy with cognitive therapy, (CBT) which combined Wolpe's desensitization therapy with cognitive therapy, behaviour rehearsal and spiritual therapy. This approach has reportedly been significantly effective in treating Muslim patients. In CBT, Badri emphasizes how our thinking and beliefs cause our emotional responses. He explains that in order to treat a person with psychological disorder, the therapist needs to apply a simple and single-indicative disorder that provides him or her with a stimulus-response paradigm. This therapy can be done with a normal person with phobia caused by a car accident. However, for patients with depression, the therapist needs to change the thinking and beliefs of the patient to be in line with a belief in God, a higher power, who has control of things and the supreme power to cure all conditions. The approach puts a lot of emphasis on religion and spirituality in the healing process. Therefore, CBT therapists will likely integrate religion into their therapy sessions. .

Badri (1979) has vast experiences in treating patients with psychological disorders. One of his patients was a young female Morrocan, who suffered from generalized anxiety, depression, feelings of inadequacy, and phobic reactions. She was admitted for treatment twice within a year, where she was treated by a harsh native healer. However, her condition did not improve, even after seeking treatment from both traditional and modern psychotherapies, or after taking drugs. Her improvement came about only after she was treated with Qur'anic verses, having accidentally heard Badri's recitation to another Muslim patient to provide moral support for the patient who about to leave the hospital. The passage from the Qur'an read by Badri was about forgiveness of sinful behaviour. To his surprise, the female Morrocan patient reacted with an unexpected tearful emotion (Badri, 1979). Since then, Badri was asked to treat her by reading Qur'anic passages that were related to Allah's forgiveness of all sins. The treatment was effective because Badri also explained the verses in simple language, which brought the Morrocan patient to make emotional confessions, which eventually led to her improved condition.

Based on Hassan Langgulung's theory of the diseases of the heart as possible causes of mental illness (1986) and Malik Badri's theory of Islamic spiritual treatment (1979), the researcher decided to adopt both of their psychological approaches as the theoretical framework for the current study.

\section{LITERATURE REVIEW}

In the current research literature, there is a significant amount of concern in determining the relationships among spiritual, religious and health variables. Johnstone et al. (2012) found that following a faith does not automatically guarantee good mental health. In terms of the relationships among faith tradition, spirituality, religion and congregational support, they found that Muslims were the most spiritual among their groups of respondents, while Jews were the least spiritual. The Muslims and Protestants were more frequently engaged in organized religious activities compared to the Jews and Buddhists. Moreover, in terms of faith tradition and personality characteristics, different faith traditions reported different personality characteristics in terms of extraversion and openness, but not neuroticism, agreeableness or conscientiousness. For instance, the Muslims and Catholics were less likely to be open to new experiences given the more structured nature of their religious practices and beliefs, which required strict adherence to specific religious routines. In finding out the relative degree of association between health outcomes and personality versus spiritual variables, it was revealed that physical health perception was mainly related to positive personality traits such as extraversion, the lack of negative personality traits such as neuroticism and conscientiousness, 
and high frequency of religious activities. Mental health perception was mainly related to the lack of negative personality traits such as neuroticism and perfectionism, and more willingness to forgive or believe in a forgiving higher power. Personality variables had stronger relationships with health outcomes compared to spiritual and religious variables.

Spirituality can be an important factor to those with psychiatric disabilities. Fukui, Starnino and Nelson-Becker (2012) revealed that people with mental illness tend to recognize their desire for spiritual well-being when they tried to make sense of life within the social restrictions that might surround their illness. Regardless of the severity of psychiatric symptoms, religious attendance, large social networks and sense of control are three important aspects for spiritual well-being. This was due to the fact that attending religious activities might help those with psychiatric disabilities to find their path when searching for the meaning of life. Meanwhile, a large social network is helpful in enhancing an individual's self-efficacy to obtain life goals. It is easier for persons affiliated with a religious community to ask for help when help is indeed needed.

According to Picco et al. (2013), the prevalence of seeking a lifetime religious or spiritual advisor among mental health patients was $6.6 \%$, while a lesser percentage $(2 \%)$ sought help from a religious counsellor on a 12-month basis. Most of the patients in Picco et al.'s study reported being satisfied with the religious support they received, and considered it to be very useful. This shows that religious or spiritual healing plays a significant supportive role for people with mental illness, although it is not the most common source of help. The study also found that Christians were more likely to seek help from religious and spiritual advisors for mental health problems, compared to Buddhists and Hindus. Those with lifetime dysthymia, bipolar disorder or generalized anxiety disorder were more likely to get consultation from religious or spiritual advisors. However, in terms of socio-demography, gender, ethnicity and education levels were not related with help seeking from religious and spiritual advisors (Picco et al., 2013).

Ally and Laher (2008) explored Muslim faith healers' perceptions of mental and spiritual illness, and categorized them into three categories, namely the understanding of mental and spiritual illnesses, their causes, and treatment or healing methods. The respondents, who were faith healers, explained that in Islam, an individual is conceptualized as being a combination of four interacting parts, i.e., the mind (Aql), body (Jism), self (Nafs), and soul/spirit (Ruh). These four parts need to interact continuously among each other to maintain a harmonious balance in the body. Diseases are likely to occur if the balance in the body is interrupted for some reason. The faith healers believed that mental illness has dualistic causes. For instance, they acknowledged that just as "physical illnesses can be brought on in a natural way, mental illness can also be brought on in a natural way" (Ally \& Laher, 2008, p. 51). The faith healers' description of mental illness was also linked to how mental illness was conceptualized in academic literature, such as in the DSM-IV-TR (2004), which conceptualized the condition as a manifestation of a behavioural, psychological or biological dysfunction in an individual. They believed that spiritual illness cannot be diagnosed by any mechanical means or any other instruments, describing the illness as presenting various physical symptoms of unexplained aches and pain and unexplained abnormal behaviour.

Many teachers have been reported to have a high degree of stress and burnout (Manju, 2018; Arvidsson et al., 2019), but some may find satisfaction in working with children, variation and unpredictability, cooperation and teamwork, and autonomy, as discovered by Skaalvik and Skaalvik (2015). The teacher respondents in their study were happy to see children learn, and found contentment in helping them with school learning. The variation and unpredictability of teaching was also a source of satisfaction as monotony on the job caused 
boredom and stagnation which may, later on, trigger a depression. When no two days were alike, the teachers were more excited and motivated to seek out new challenges in each lesson. Sharing teaching and learning responsibilities with all students made them content, as did the teamwork they engaged in when planning and conducting lessons. The teachers mentioned that they had the flexibility and independence in teaching the students. They appreciated the opportunity to choose where and when to prepare for teaching. In terms of challenges and stress, the teachers cited the following factors as stressors in the teaching profession--workload, time pressure, adapting teaching to students' needs, disruptive student behaviour, value conflicts, lack of autonomy, teamwork and lack of status. Exhaustion and psychosomatic symptoms, reduced accomplishment and loss of self-efficacy and negative affect and loss of self-esteem were found to be the consequences of workload and strains.

The strategies applied in coping with the challenges and strains differed among the teacher respondents. Younger teachers worked harder to handle everything and to always be well-prepared. They avoided taking sick leaves. The extreme amount of working hours was their biggest cause of severe exhaustion levels. Only one young teacher mentioned that he tried to cope by exercising, jogging and hiking. Middle-aged teachers reported to be highly ambitious and worked long hours to prepare for classes. But, unlike their younger counterparts, the middle-aged teachers would use their sick leaves as a self-protective strategy. In other words, they actively asked doctors for short sick leaves, which normally lasted from one to three weeks. They also conveyed a strong desire to leave the teaching profession, either permanently or for a certain period of time. One of the reasons for wanting to leave the teaching profession was to try other jobs. Some of the middle-aged teachers reduced their teaching hours in order to reduce their workload. The senior teachers were still highly ambitious although they were actively utilizing short-term sick leaves as a strategy to escape from the stress and workload. Some of them lowered their aspirations and reduced the amount of time they spent to prepare lessons. Few chose to exercise on a regular basis, but made sure that they got enough sleep and had some time to relax on the sofa after school hours. These were the means of coping with physical and emotional stress reported by teachers in Skaalvik and Skaalvik (2015).

In addition to the findings of Skaalvik and Skaalvik (2015), Doménech-Betoret and Amparo Gómez-Artiga (2010) revealed that teachers who applied active coping strategies were more often able to overcome pedagogical barriers, felt more efficacious in their work, and reported less depersonalization. Teachers who seldom applied active coping in a heavy workload situation suffered more depersonalization. Wang and Dai (2011) investigated the social support and coping styles of female teachers in middle schools in Wuhan, China and found some gender differences. They showed that female teachers were more mature than the average groups in the city of Wuhan, while male teachers were more mature in coping with different life events. In coping with pressure and deadlines, female teachers tend to solve their problems on their own, whereas male teachers avoided stress with good anti-stress mechanisms. Additionally, female teachers scored significantly lower on social support--most likely because men tend to have support more readily available from family members, especially their wives, whereas female teachers had to face the same pressure as the male teachers, and at the same time, had to take care of family members. On the average, it was found that female teachers were busier than male teachers. They had less free time, which caused a psychological imbalance and affected their relationships with their families, colleagues and friends.

It is not surprising to find the sources of stress to include the lack of ability to neutralize job stress with quality family time. Relaxing activities with family and friends have a miraculous way of healing physical, emotional and psychological disturbance, but teachers often cannot find time for these activities. Richards (2012) found that many teachers were highly committed, often bringing back half-finished work to be completed at home. Lack of 
control over school decisions, teaching students who were not motivated, teaching needy students without adequate support, and feeling the constant pressure of being "accountable" were huge sources of teacher stress. Richards (2012) also revealed some coping strategies that these teachers applied, which included making time for themselves, family and physical exercises. Friends and family were relied on as support systems that took away stress, anxiety and depression, in addition to getting enough sleep, eating a healthy diet, and practicing meditation. Some even experimented with "fun teaching" to inject joy and excitement into their daily task of teaching, determined to embrace a positive attitude towards the teaching profession. Some learned to let things go to avoid stress, especially if the causes of stress were things not within their locus of control. Almost all of the coping methods described in the literature discussion herein were physical and social in nature. The lack of research and coverage on religious coping, especially among Malaysian Muslim teachers, prompted the undertaking of the current study.

\section{Research Objectives and Questions}

The objectives of the present case study were to explore Malaysian Muslim teachers' coping strategies in dealing with mental health issues and to understand the relationship between spiritual practices and mental well-being. The research questions were:

1. How do the Malaysian Muslim teachers cope with mental illnesses?

a) How do they prevent themselves from being mentally ill?

b) How do they prepare themselves in dealing with mental health issues?

2. What is the relationship between spiritual practices and mental well-being?

\section{METHODOLOGY}

\section{Research Design}

This study employed the case study method to explore the coping strategies used by Malaysian Muslim teachers to deal with their mental health issues. The case study method, which comprised semi-structured interview protocols, was judged suitable for this inquiry as it could gain an in-depth understanding and insight into the phenomenon.

\section{Participants}

The participants were six teachers teaching in six different government schools in Kuala Lumpur. They consisted of two male and four female teachers aged between 25 to 58 years old. They taught Bahasa Melayu, Music, Arts, Civic Education, Science, Mathematics, and Chemistry in their respective schools. The teachers each had at least three years of teaching experience, and had been diagnosed with certain symptoms of mental illness. At the time the study was conducted, the teachers were on medication but were instructed to continue teaching like the rest of their colleagues. They were chosen via purposeful sampling with the help of the Kuala Lumpur Education District Office. For the purpose of reporting, they will be referred to as Aminah, Zainab, Fatimah, Ahmad, Amin, and Asma. The researcher chose Muslim teachers as study participants as her objective was to find out Muslim teachers' coping strategies and how they perceived the relationship between spiritual practices and mental illness. 


\section{Data Collection}

The interview sessions with all participants took between forty to ninety minutes. The participants decided on the date, time and venue of their respective interviews. All interviews were conducted in a conducive environment identified and as agreed by both participants and researcher. To preserve the richness and authenticity of the data, the conversations were allowed to be spontaneous. The participants were encouraged to express their thoughts and feelings using the language they were comfortable with, be it English or Malay, both of which were spoken by the researcher.

\section{Treatment of the Data}

Data from the interviews were recorded and manually transcribed verbatim into a narrative text. Transcriptions of the interview were coded using the pseudonyms ascribed to the participants, with the relevant dates and places of interview mentioned, as well as the discourse units (DU). A DU is a numeric representation assigned to utterances without pauses from either the researcher or participants. In this regard, the researcher also assigned a DU to every detail in the transcriptions, including to fillers like "aaa" and " $m m m$," as well as to pauses, phrases and incomplete sentences. DU coding is commonly used in individual interview transcriptions to assist the researcher to make quick and easy references when analysing and interpreting data. It serves as a means for an audit trail of the data.

An organizational counsellor from the Kuala Lumpur Education District Office and a psychiatrist from the Tengku Ampuan Rahimah Hospital were interviewed for data triangulation. For inter-rater reliability, the researcher requested two independent raters to develop their main ideas for all interview questions based on the selected discourse units. The two raters were organization counsellors from two Education Offices in different districts in Kuala Lumpur. To calculate the percentage of inter-rater reliability, the researcher added the total number of agreements on the themes and divided it with the total number of both agreement and disagreement. The outcome of that calculation was then multiplied by a hundred to get the percentage. Hence, by engaging multiple sources of data triangulation, the researcher established the overall credibility of the data on religious coping.

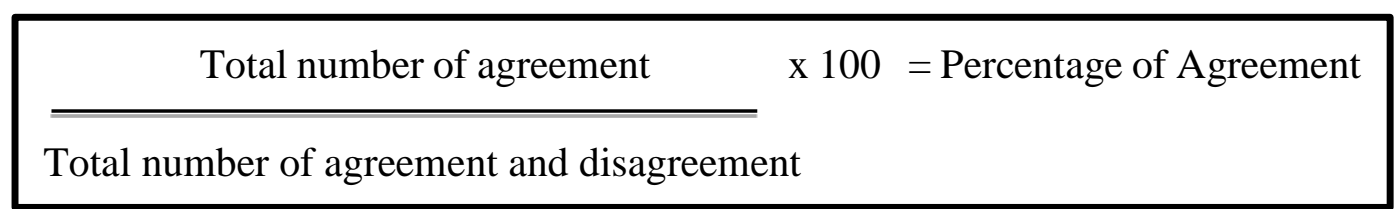

Figure 2. Inter-Rater Reliability Formula

\section{FINDINGS}

The study generated four themes from the data on teachers' coping strategies: a) medical treatment; b) religion; c) family and societal support; and d) positivity, which were then analysed.

\section{Medical Treatment}

Fatimah, Amin and Asma agreed that getting appropriate medical treatment was the first crucial 
step that needs to be taken. An illness such as theirs should never be ignored, or be silently prayed to go away. For instance, Fatimah's husband brought her to see a psychiatrist after being informed by her colleagues about her mood swings and changes of attitude at the workplace:

"So, my husband brought me to see a doctor."

Amin admitted that it was beneficial for him to seek professional treatment. He voluntarily went to see both a counsellor and psychiatrist after going through a life predicament:

“...I tried seeking people [for help]."

“....To get an opinion."

Asma added that after her first meeting with the psychiatrist, she requested for a medical leave as she was totally depressed and was not interested to communicate with anyone, including her own spouse and children. She preferred to lock herself up in her bedroom:

"Besides from taking medications, I asked the doctor to give me medical leave."

"Because I could not stand looking at my colleagues, to the extent of not even wanting to talk to my husband and children."

"Yes, I prefer to lock myself in my room."

In summary, it was revealed that seeking professional help and getting medical treatment were key to helping these teachers to overcome their illness.

\section{Religion}

This theme has four underlying subthemes: a) prayers and zikr; b) Qur'an recitation; c) protective factor; and d) diseases of the heart.

\section{Prayers and Zikr}

Aminah, Zainab and Asma believed that one of the crucial steps in preventing themselves from being mentally ill is by getting closer to Allah. This can be done by performing night prayers and reading the Qur'an on a daily basis. However, Asma added that she also performed the sunnah prayers:

"I perform optional prayers, recite selawat Syifa. These give me strength and I teach myself to think positive."

Amin confessed that prior to his mental condition, he did not perform daily prayers regularly, but only when he felt like it. However, after getting professional treatment from a psychiatrist and seeking the help of a counsellor, he had changed into a better Muslim. He believed as a Muslim, it is always good to go back to the deen:

"... in the past, praying was not a priority for me ..."

"... whatever happens, we should go back to the religion."

Asma believed that spiritual practices were helpful in shaping her positive mental well-being. The practices strengthened her belief in God--that only Allah could cure her from both mental and physical illnesses:

"... I think it helps."

"Whatever it is we have to remember that it happens with Allah's will." 
According to Fatimah, sunnah food such as honey and dates also helped her in maintaining her health and anxiety levels. Consuming these food items had found its way into her daily diet.

"...I keep zam zam drink, dates, honey in the teachers' room."

"I even have pomegranate juice."

Aminah and Fatimah believed that spiritual practices bring calmness into their lives. Aminah agreed that positive spiritual practices would lead to positive mental well-being. However, she also believed that those with positive spiritual practices would be tested and could suffer from mental illnesses. In other words, religious people who consistently perform prayers, read the Quran, and recite zikr could also have the possibility of suffering from mental illnesses:

"...if we engage in positive spiritual practices, then we would have positive minds. But it is not unlikely that those who never leave good deeds such as getting closer to Allah, and do zikir also face challenges with these kind of illnesses..."

All participants believed strongly in the healing power of spiritual practices in their daily lives, which included the five daily prayers and reading the Holy Qur'an. On top of the five obligatory prayers, Aminah and Asma added that they also performed sunnah prayers.

\section{Qur'an Recitation}

Aminah added that she made a habit of reciting istighfar and reading Yassin in her daily life, while Asma recited Ayatul Kursi, Salawat Shifa and made sure she recited Al-Fatihah for both her parents and the Prophet Muhammad (peace be upon him) on a daily basis:

"First of all, say the istighfar many times... second... perform the mandatory and optional prayers. Then read Yassin a lot. Reading Yassin is like the best medicine for me. That is why I have been reading it on a daily basis since I got sick."

"I recite selawat Syifa."

"I perform optional prayers, [and] recite selawat Syifa. These give me strength and I teach myself to think positive."

"I would recite Bismillahirahmanirrahim Fahiyyi'lana min amrina rasyada, wa ahillana min amrina rasyada, wa aqrabil musliman [34:10]. Baca Qul Ya, baca Allahumma maftah alaina', read Ayat Kursi four times. After that I would read Al-fatihah."

All participants agreed that spiritual practices affect their mental well-being. Aminah and Fatimah mentioned that these practices instilled peace and contentment in their hearts that resulted in mental well-being:

“..spiritual practices such as zikir..aa..prayers would give us a greater sense of calmness that would lead us to act calmly."

"... of course when we think calmly, our heart would also be calm." 


\section{Protective Factor}

Zainab added that these practices were considered as a protective factor for her. She admitted that she was able to focus on her work and daily routine when she performed these spiritual practices.

“... either the effectiveness of the medicines or perhaps due to zikir and reading Quran."

Ahmad mentioned that spiritual practices could also act as a preventive factor. For instance, when he was depressed, the psychiatrist who treated him asked if he had any intentions of committing suicide. He replied that he had thought about it, but never intended to really do it, as he was aware that it was a sin to commit suicide:

"It [committing suicide] occurred in my mind but I did not intend to do so."

He also mentioned that the spiritual practices helped him to face his problems, instead of running away from them or avoiding them. These practices made him muhasabah or account for his sins or deeds and made him want to go back to fitrah.

"Do not run from it [problems]."

"So, we go back to fitrah."

Fatimah stated that performing spiritual practices gave her the courage to survive and move on with her life:

“...it gives me courage (to move on with life)."

Amin stated that the spiritual practices made him realize the importance of prayers and reciting $d u^{\prime} a$ :

"Praying is important."

"... like when we are in low mood, there is nothing we can rely on."

"... we take ablution, we pray, pray to God, insyaAllah. That is correct."

\section{Diseases of the Heart}

All participants had different views about the diseases of the heart. Aminah believed that the diseases of the heart had to do with negative thoughts. She also mentioned that it could happen when a person starts to compare himself with others and feels dissatisfied when others have more than he/she does:

"For me it is based on the attitude, negative attitudes would influence our mental [state], the way we think and eventually, our mental health."

Fatimah stated that the causes of diseases of the heart vary. For example, diseases of the heart would exist when a person is so focused on gaining fame and success that he or she would neglect his or her ethical values:

"Depends on the individual. It may be related but not to all individuals. Maybe certain individuals are longing for status. But for me, I do not think it is related (with mental illness)." 
Ahmad indicated that the diseases of the heart are related to the mazmumah characters. He believed that those with faith would not get involved with these diseases as they would always strive to get closer to Allah:

"... it is called as characteristics of mazmumah".

Similar with Zainab, Asma agreed that diseases of the heart existed when a person is dissatisfied with himself or herself. Perhaps the person is not satisfied with an issue that causes him or her to feel confused, leaving them with mixed feelings that are more likely to be negative:

"This thing could happen if we keep on observing others and we feel like others have more than us...We compare ourselves with others. So, we feel imperfect, of course there would be envy."

“... it is caused by having feelings of dissatisfaction that are holding back

a person and maybe the person is confused, his or her thoughts are confused and all they could feel was anger..."

Based on the interview, one similarity that could be found among all participants is that all of them believed that their illnesses had nothing to do with the diseases of the heart. Their perceptions of diseases of the heart vary. Some of the teachers believed that it occurred when a person is not satisfied with what other people have. Aminah believed that it occurred due to having negative thoughts, whereas Zainab believed that it was due to "the whispers of evil":

"It has to do with whisperers, perhaps evil's whisperers."

From the above, it can be summarized that spiritual practices may affect a person's mental wellbeing. Spiritual practices bring calmness in people's lives. It also serves as a preventive and protective factor against mental ill-health. It gives courage and strength to these teachers to face their problems. Some of the spiritual practices engaged in by the teachers included performing the obligatory five daily prayers, reading Quran, istighfar, ayat kursi, salawat shifa, and reciting al-fatihah. All teachers believed that their illnesses had nothing to do with diseases of the heart.

\section{Family and Societal Support}

All participants, except Zainab, admitted that they had full support from not only their family and friends, but also the school administration.

"Alhamdulillah my family has always been supporting me... The school administrators have always been giving positive support, especially the school principal, senior assistant..."

"I recovered because of my friends, and support from my husband."

Aminah responded that her family, especially her own mother, would always ask how things are going for her. She would ask if she was emotionally stable and made sure the rest of the family members would not hurt her feelings. They would all try to make her happy and become more sensitive towards her:

“...the way they showed their support was by asking, not only by asking how am I doing, but also how I feel, and doing something that makes me happy...they take care of my feelings as I am more and more sensitive..." 
Aminah's mother would also keep her company if she could not sleep at night. She would spend time talking to Aminah in order to make sure that she was fine and not in an extreme mood. Besides that, during the recovery period, the school management gave her less workload compared to other teachers:

“...if I am not asleep yet, my mother would not sleep, she would wait (until I fell asleep)...my mother is more careful and more aa... sensitive with my behavioural changes."

“...the school administrator gives less workload, during my recovery period."

Fatimah explained that when she was sick, her husband treated her in the same way as when she was normal. He would have conversations with her and would took her out even if she felt like locking herself in her room:

“...my husband would ask me out even though I was sick at that time....he would talk to me like usual. This means that sometimes he did not treat me like a sick person..."

He would try to make Fatimah happy. He would not be angry or upset if he saw the house in a mess during the recovery period because he knew Fatimah neglected the house chores for a reason:

"He was not angry (for not doing any house chores)...I did not cook for quite some time."

Fatimah also got support, love and care from her children. They understood her situation and tried not to burden her. They would make sure that their mother was able to get some rest and took the medicine on time:

"[My children would tell me]...Mom, sleep. Mom, take your medicine.

Take them now..."

Not only that, during her long medical leave, Fatimah's school principal and colleagues persuaded her to come to school if she was bored at home. They encouraged her to come to just visit the school to socialize with her colleagues as the school principal was concerned that she might get too bored and depressed by sitting alone at home during the day:

"...if I was bored at home..aa..the Principal would allow me to come to school and sit at the teachers' room..aa..to talk to my colleagues. In other words, he allowed me to stay in the teachers' room and have some conversations so that I would not feel bored at home since he was concerned if I became stressed. So, I could come to school even though I was on MC."

Even Fatimah's students would greet her at school and ask how she was doing, which made Fatimah feel happy and want to be free from the illness:

"...when they come to school, they would ask me and say, "Alhamdulillah, teacher has recovered"." 
Ahmad stated that his wife and children were all very supportive. He lived alone in Kuala Lumpur, while his wife and most of the children were living in Kota Bharu, Kelantan:

"Anyway, I... was alone in Kuala Lumpur."

"My family was in..in Kelantan."

He normally travelled to Kelantan every two weeks to visit them, and to receive medical treatment at the Kubang Kerian Hospital, which was in his hometown. His wife, who was a nurse at the hospital, helped to arrange his doctor's appointments:

“... she [my wife] would arrange for appointments."

Asma reported that she got support from her family members and spouse, but not her colleagues. She still contacted the school principal from her previous school as they were very close to each other. They became close ever since the principal's husband suffered from cancer that led to his death:

"We were so close. And she loves me so much....Her husband passed away due to cancer."

When the principal's husband was still alive, Asma and the principal always talked about cancer and shared any beneficial information or tips on how to cure it:

"I asked her opinion..aa..even though we have different religions. She is a Chinese-Christian."

Asma related that at first, her husband was too busy with work that he had no time to pay attention to her. He seldom accompanied her to see the doctor. This made her lonely and unhappy. So, she sent messages to him and told him how she felt. After a while, the husband changed. He started to give more attention to her. Sometimes he took leaves to bring her to the doctor for her appointment.

"...lately he has been giving much attention."

Besides her husband, Asma was also very close to her mother. She would normally call her mother every day to share stories and ask if everything was fine. If she was too busy to call her mother, her mother would call her up. They would talk to each other at least once a day.

"My mother always calls. I also call her every day."

Zainab believed that she did not receive any support from family members and friends. Although her mother always encouraged her to go for follow-up treatments and take the medicines prescribed, she felt uneasy with that kind of support:

"My mother encouraged me to take the medications."

Hence, she decided to keep her problems to herself and not share them with others:

"I prefer to keep [my problems] to myself. I do not want to share them with others....I do not like to share [my problems] with others."

To sum up, it was discovered that all teachers believed that they received support from family 
members, schools, and colleagues. Only Zainab felt that she did not receive any support from close family members.

\section{Positivity}

Interestingly, Ahmad asserted that it was always good to be kind and positive, especially towards your immediate family members such as spouse and children, because they would the ones supporting and assisting you through the difficult times:

"In any situation, we must communicate, connect in the best manner...Because they are the ones to help us when we need help...[to] take good care of us."

Ahmad believed that the positive relationship with his current colleagues had helped him to cope with his situation. His colleagues still respected him despite his mental health issues:

"I did not only shake hands with the deputy, but he also hugged me."

"...we have to know ourselves, reflect upon ourselves, [know] who we are...."

As for Aminah, she would find a hobby or an interest to keep her busy. She believed that the hobby would distract her from getting bored and thinking about her illness. She had much interest in music. Thus, she would compose lyrics and songs whenever she had the time:

“...like I said just now, socializing..ha..having friends..aa..listening to music because that is my hobby, I like to play musical instruments, I like to write songs."

"... being involved in those activities is much better than sitting around and thinking about my feelings, sitting at home..."

Fatimah mentioned that after her long medical leave during the recovery period, she started to enjoy going back to school and felt happy in the school environment. She was also happy with the full support received from her colleagues:

“...The school principal gave his support...I was happy at school with my colleagues..."

The school had reduced her responsibilities by taking away her administrative position; she was the school's Treasurer for the Parent Teacher Association (PTA). Hence, she became less busy and had more time to focus on her health and lessons. She also continued to take the medicine that was prescribed by the psychiatrist. She was glad when she found out the number of teachers in her school had doubled after she returned to work from her long medical leave. There were only forty teachers in her school. However, the number of teachers had increased to eighty after she returned to work months later:

"There were not many teachers in previous years, only 40 . Now we have $80 . "$

Meanwhile, Amin reminded himself to exercise care and caution to prevent the illness from coming back. After going through the recovery period, he realized that the illnesses could recur if he was not careful enough, something that he regarded as a test from God: 
"InshaAllah with what I have gone through inshaAllah I could [survive from the illnesses], but we cannot be so sure."

"I am afraid if God wants to give bigger test."

As for Asma, her coping strategy was to share her problems with her spouse:

"... another way is for me [to cope] is by sharing [my problems] with my husband."

Her husband had become more supportive and understanding after Asma expressed her feelings and thoughts to him, which also helped Asma in coping with her illness.

In summary, the preceding analysis has shown how different teachers found different strategies to cope with their illness and daily issues. The strategies used highlight the importance of having positive feelings and a positive attitude towards the situation. For instance, Aminah would find a healthy hobby to busy herself with so she would not focus too much on her emotional state. Fatimah and Ahmad decided to have a positive relationship with others, while Asma realized that sharing her concerns with her spouse helped her to cope. Amin believed that he needed to be careful and alert so that he would not fall back into the previous emotional predicament

\section{DISCUSSION}

\section{Spiritual Practices on Mental Illness}

A majority of the participants believed that spiritual practices brought calmness into their lives. Performing prayers, reading the Holy Quran, reciting zikir and salawat led them into a calm mental state. Spiritual practices also led to having a positive psychological well-being. This concurs with Badri (as cited in Abdul Wahab Khan, 2015) who believed that Islamic spirituality would bring greater benefit for those who suffer from mental illness. Ahmad considered spiritual practices to act as a preventive factor, whereas Zainab considered them to act as protective factor. In other words, these practices are shields against psychological and emotional instability. Spiritual practices could serve as both preventive and protective factors from severe mental illnesses. For example, Ahmad mentioned that he had thought of committing suicide when he was feeling depressed. However, the thought disappeared when he suddenly remembered that it was a big sin to commit suicide. He added that spiritual practices gave him the strength to confront his problems, rather than running away from them. It taught him to perform muhasabah or self-reflection to account for his sins or deeds.

This finding supports the theoretical propositions of Badri (as cited in Abdul Wahab Khan, 2015), who encouraged Muslims to carry out spiritual activities including spiritual contemplation and tasbeeh to maintain a healthy and stable psychological state. Spiritual practices helped the participants to become more focused on their work and daily routines, in addition to creating better Muslims out of them. These reports are consistent with Badri's assertions (as cited in Abdul Wahab Khan, 2015) that as Muslims, we must believe in predestination and the overpowering command of Allah the Al-Mighty. The belief creates in us an acceptance of God's will and power, and that we have no complete control over everything in our lives. Badri advocated engaging in regulars prayers to keep a strong self in facing trials and tribulations. Furthermore, the above findings also support Fukui, Starnino and NelsonBecker (2012) who revealed that individuals with mental illnesses were likely to recognize their desire for spirituality and spiritual engagement when attempting to make sense of life within the social restrictions that surrounded their illnesses. They also found that religious attendance, large social networks and a sense of control were three important aspects for spiritual wellbeing. 
Of all the participants, only Fatimah and Asma sought help from an ustaz or religious advisor. Fatimah sought the advisor's help a few times during her recovery period, stopping the sessions upon her full recovery. Asma, however, continued with her sessions with the advisor as she was seeking treatment to alleviate both her mental and physical illnesses. Normally, the religious advisors would provide them with some spiritual water that had been treated with certain Quranic verses. They also shared some $d u^{\prime} a$ or verses from the Quran that they could apply and recite in their daily life in order to cope with the illnesses. This finding supports that of Picco et al. (2013) who showed that religious advisors played a significant supportive role for individuals with mental illnesses even though they were not the most common source of help.

\section{Diseases of the Heart and Mental Illness}

Some of the participants believed that their mental illnesses had nothing to do with diseases of the heart such as greed, anger, hatred and envy. However, based on their descriptions, there were elements of diseases of the heart such as jealousy or envy as indicated by Langgulung (1986). For example, Zainab mentioned that diseases of the heart had to do with evil whispers that told her to do bad things. It normally happens when a person starts to compare himself with others and starts feeling dissatisfied with what they have or do not have in comparison to others. Nevertheless, this factor was not seen as strong as other factors that had caused the participants' mental illnesses. Fatimah added that the cause of these diseases varied. For instance, it could exist when a person was so focused in gaining fame and success that he neglected his ethical values. Ahmad associated diseases of the heart with bad (mazmumah) character traits. He was confident that those with a strong faith would never get these diseases as they are protected by their closeness to God.

\section{Coping Strategies Applied in Daily Life}

All of the six participants agreed that one of the coping strategies applied was to be spiritual and get closer to God. This could be done by performing not only obligatory prayers, but also the sunnah prayers that could be performed at night. Reading the Holy Quran also helped to cope. Fatimah added that eating sunnah food such as honey and dates also brought many benefits to her health status and anxiety levels. Getting the appropriate medical treatment and consuming the medications prescribed were important. Aminah admitted that she would make herself busy in order to distract herself from thinking about her feelings. She maintained a hobby in music, which was to compose lyrics and songs.

To Ahmad, being kind and positive to others, especially family members and colleagues, was beneficial to him as he depended on them to get through tough times. He also made many scrapbooks full of newspaper articles that he found interesting and inspiring. These scrapbooks, which were initially made to fill his free time during recovery, have now became a hobby. He managed to create 75 scrapbooks within two years. These findings agree with Skaalvik and Skaalvik (2015) who revealed that in dealing with stress, young teachers coped by exercising, jogging and hiking, while senior teachers coped by getting enough sleep and rewarding themselves with simple relaxation like lounging in the sofa after school hours. Meanwhile, Doménech-Betoret and Amparo Gómez-Artiga (2010) found that teachers who applied active coping strategies were better able to overcome pedagogical barriers, demonstrated more efficacy at work, and experienced less depersonalization. In addition, Richards (2012) found other effective coping strategies used by mentally affected patients, which included making time for themselves, getting enough sleep, eating a healthy diet, 
meditating, and embracing a positive outlook and attitude. All of these were reported by the teachers in the study.

\section{CONCLUSION}

The current study has been able to show that seeking professional help, getting medical treatment, and having full support and cooperation from others gave patients with a mental predicament an inner strength to cope with their condition, which prevented the exacerbation of their mental illness. Islamic spiritual practices, such as performing the five daily prayers, reading the Qur'an, and reciting zikr, were also fundamental to the healing process. For future research in the same area of study, researchers are recommended to conduct a phenomenological inquiry into participants' experiences of mental illness. Such an undertaking should allow a close observation and scrutiny of the causes and characteristics of the varying mental conditions, giving the public a better understanding of what mentally ill participants experience. 


\section{REFERENCES}

Abdul Wahab Khan, Rahmattullah Khan. (2015). An interview with Professor Malik Badri about his contributions to the Islamisation of psychology. Intellectual Discourse, 12(1), 159-192.

Ally, Y., \& Laher, S. (2008). South African Muslim Faith Healers perceptions of mental illness: Understanding, aetiology and treatment. Journal of Religious Health, 47, 45-56.

Arvidsson, I., Leo, U., Larsson, A., Håkansson, C., Persson, R., \& Björk, J. (2019). Burnout among school teachers: Quantitative and qualitative results from a follow-up study in southern sweden. BMC Public Health, 19. Retrieved from http:// dx.doi.org /10.1186 /s12889-019-6972-1

Badri, Malik. (1979). The dilemma of Muslim psychologists. London, UK: MWH London Publishers.

Bakar, A. R., Mohamed, S., Suhid, A., Hamzah, R. (2014). So you want to be a teacher? What are your reasons? International Education Studies, 7(11), 155-161.

Bauer, J., Unterbrink, T., Hack, A., Pfeifer, R., Buhl-Grießhaber, V., Mu“ ller, U., Wesche, H., Frommhold, M., Seibt, R., Scheuch, K., \& Wirsching, M. (2007). Working conditions, adverse events and mental health problems in a sample of 949 German teachers. International Archives of Occupational and Environmental Health, 80, 442-449.

Chong, S. T., Mohamad, M. S., \& Er, A. C. (2013). The mental health development in Malaysia: History, current issue and future development. Asian Social Science, 9(6), 1-9.

Crabtree, S., \& Chong, G. (2000). Standing at the crossroads: Mental health in Malaysia since independence. In A. Haque (Ed.), Mental Health in Malaysia: Issues and Concerns. Kuala Lumpur: University Malaysia Press.

Doménech-Betoret, F., \& Gómez-Artiga, A. (2010). Barriers perceived by teachers at work, coping strategies, self-efficacy and burnout. The Spanish Journal of Psychology, 13(2), 37-654.

Evans, P. (2003). The relationship between management style and teacher stress. Nottingham, UK: National College for School Leadership.

Fukui, S., Starnino, V.R., \& Nelson-Becker, H. B. (2012). Spiritual well-being of people with psychiatric disabilities: The role of religious attendance, social network size and sense of control. Community Mental Health Journal, 48, 202-211.

Lee, L.T. (2017, April 9). Good Mental Health Vital for Productivity. The New Straits Times. Retrieved from http://www.nst.com.my/news/2017/04/228608/good-mental-healthvital-productivity

Hooftman, W. E., Mars, G. M. J., Janssen, B., de Vroome, E. M. M., \& van den Bossche, S. N. J. (2015). Nationale Enquête Arbeidsomstandigheden 2014. Methodologie en globale resultaten [National Survey Working Conditions 2014. Methodology and global results]. Retrieved from TU Delft Online Library: http://publications.tno.nl/ publication/34616775/NPtzyl/hooftman-2015-nationale.pdf 
Jamaiyah, H. (2000). Community mental health in Malaysia: Marriage of psychiatry and public health. Buletin Kesihatan Masyarakat Isu Khas, 155-166.

Johnstone, B., Yoon, D. P., Cohen, D., Schopp, L. H., McCormack, G., Campbell, J., \& Smith, M. (2012). Relationships among spirituality, religious practices, personality factors, and health for five different faith traditions. Journal of Religion and Health, 51, 1017-1041.

Jurado, D., Gurpegui, M., Moreno, O., \& de Dios, L.J. (1998). School setting and teaching experience as risk factors for depressive symptoms in teachers. European Psychiatry, $13,78-82$.

Langgulung, H. (1986). Teori-teori kesehatan mental. Jakarta: Pustaka Al Husna.

Manju. (2018). Burnout in teachers: Causes, consequences and intervention. Indian Journal of Health and Wellbeing, 9(3), 510-512. Retrieved from http://210.48.222.80 /proxy. pac /docview/2030128175? accountid=44024

Mccarthy, C. J., Lambert, R. G., Lineback, S., Fitchett, P., \& Baddouh, P. G. (2016). Assessing teacher appraisals and stress in the classroom: Review of the classroom appraisal of resources and demands. Educational Psychology Review, 28(3), 577-603. doi: http://dx.doi.org/10.1007/s10648-015-9322-6.

Mental Disorder Is Going To Affect Over 3 Million Malaysians By 2020 - Will You Be One Of Them? (2015, December 4). Retrieved from http://www.malaysiandigest.com/news/582570-mental-disorder-is-going-to-affectover-3-million-malaysians-by-2020-will-you-be-one-of-them.html

Milfont, T. L., Denny, S., Ameratunga, S., Robinson, E., \& Merry, S. (2008). Burnout and wellbeing: Testing the Copenhagen Burnout Inventory in New Zealand teachers. Social Indicators Research, 89, 169-177.

Ministry of Education Malaysia. (2012). Pelan pembangunan pendidikan Malaysia 2013-2025 [Malaysia education blueprint 2013-2025]. Putrajaya: Author.

Naring, G., Briet, M., \& Brouwers, A. (2006). Beyond demand-control: Emotional labour and symptoms of burnout in teachers. Work \& Stress, 20, 303-315.

National Health and Morbidity Survey (NHMS). (2015). Institute for Health, Ministry of Health Malaysia: Putrajaya. Accessible at http://www.iku.gov.my/images/IKU/Document /REPORT/nhmsrep ort2015vol1.pdf

Othman, Z., \& Sivasubramaniam, V. (2019). Depression, anxiety and stress among secondary school teachers in Klang, Malaysia. International Medical Journal, 26(2), 71-74.

Ouellette, R. R., Frazier, S. L., Shernoff, E. S., Cappella, E., Mehta, T. G., Maríñez-Lora, A., Cua, G., \& Atkins, M. S. (2018). Teacher job stress and satisfaction in urban schools: Disentangling individual, classroom, and organizational level influences. Behavior Therapy, 49(4), 494-508. https://doi:10.1016/j.beth.2017.11.011. 
Perveen, A., Kee, P., Khan, R. K. B. A. W., Khan, A. M., Sa'sd, F.B.M., \& Shahadan, M.A. (2017). Prevalence of psychological disorders and available of facilities in community mental health centers: A survey research study in Batang Padang District, Perak, Malaysia, 2015-2016. Journal of Psychology \& Psychotherapy, 7(325). https://doi: $10.4172 / 2161-0487.1000325$

Picco, L., Subramaniam, M., Abdin, E., Vaingankar, J. A., Zhang, Y., \& Chong, S. A. (2013). Roles of religious and spiritual advisors among adults in Singapore with mental illnesses. Psychiatric Services, 64(11), 1150-1156.

Rajaendram, R. (July 14, 2019). Teachers facing more mental pressure. The Star Online. Retrieved from https:// www.thestar.com.my /news/education/2019/07/14/teachers-facingmore mental-pressure.

Rice-Oxley, M. (2019, June 3). Mental illness: is there really a global epidemic? The Guardian. Retrieved from https://www.theguardian.com/society/2019/jun/03/mental-illness-isthere-really-a-global-epidemic.

Richards, J. (2012). Teacher stress and coping strategies: A national snapshot. The Educational Forum, 76(3), 299-316.

Skaalvik, E. M., \& Skaalvik, S. (2015). Job satisfaction, stress and coping strategies in the teaching profession-what do teachers say? International Education Studies,8(3), 181192.

Teacher Caught in Singapore Mentally Ill (2014, January 24). Retrieved from http://www. thestar.com.my/News/Nation/2014/01/24/Teacher-caught-in-Spore-mentally-ill-

Woman-has-been-on-medication-since-she-was-a-teenager-says-aunt/

Teachers Facing More Mental Pressure (2019, 14 July). Retrieved from https://www.thestar.com.my/news/education/2019/07/14/teachers-facing-more-mental -pressure

Teacher Files Lawsuit Over Transfer (2013, January 2). Retrieved from http://www.thestar.com.my/News/Nation/2013/01/02/Teacher-files-lawsuit-overtransfer/

Teacher Who Allegedly Hurt Students Could Face Stress, Mental Problems (2014, February 14). Retrieved from http://www.thestar.com.my/News/Nation/2014/02/14/Crimeteacher-punch-student/

Wahl, O., Susin, J., Lax, A., Kaplan, L., \& Zatina, D. (2012). Knowledge and attitude about mental illness: A survey of middle school students. Psychiatric Services, 63(7), 649654.

Wang, P., \& Dai, Q. (2011). A survey of social support and coping style in middle school female teachers in China. Creative Education, 2(3), 220-225.

Weisberg, J., \& Sagie, A. (1999). Teachers' physical, mental, and emotional burnout: Impact on intention to quit. The Journal of Psychology, 133(3), 333-339. 
Wesselmann, E. D., \& Graziano, W. G. (2010). Sinful and/or possessed? Religious beliefs and mental illness stigma. Journal of Social and Clinical Psychology, 29(4), 402-437.

Yeoh, S. H., Tam, C. L., Wong, C. P., \& Bonn, G. (2019). Examining depressive symptoms and their predictors in Malaysia: Stress, locus of control, and occupation. Frontiers in Psychology, 8(1411). https://doi: 10.3389/fpsyg.2017.01411 